\title{
UJI AKTIVITAS ANTIHIPERURISEMIA EKSTRAK ETANOL DAUN GEDI HIJAU (Abelmoschus manihot (L.) Medik) PADA TIKUS PUTIH JANTAN GALUR WISTAR (Rattus norvegicus)
}

\author{
Defritsevani Y. Umboh ${ }^{1)}$, Edwin de Queljoe ${ }^{1)}$, Paulina V. Y.Yamlean ${ }^{1)}$ \\ ${ }^{1)}$ Program Studi Farmasi FMIPA UNSRAT Manado, 95115
}

\begin{abstract}
In the southeast Asian Region showing prevalence for the incidence of hyperuricemia, Indonesia ranks second with 18\%. Diseases resulting from hyperuricemia (Excess uric acid) are known as gout. The use of excessive or uric acid lowering drugs such as Allopurinol can cause side effects. Flavonoids are known to inhibit xanthine oxidase, so flavonoids have the potential to be used as antyhiperuricemia agents. Green gedi leaves that have been extracted with $96 \%$ ethanol have a total flavonoid content of $41.56 \%$. This study aims to determine the potential activity of reducing uric acid levels from green gedi leaves. This type of research is an experimental study carried out in a laboratory with rat test animals with 5 kind of treatments with 3 treatments per repetition. Hyperuricemia conditioning is done by inducing potassium oxonate intraperitoneally. Group I as negative control was given 1\% CMC, group II as positive control was given Allopurinol, group III-V was treated with ethanol extract of green gedi leaves with defferent doses of $3.6 \mathrm{mg}$, $7.2 \mathrm{mg}$ and $14.4 \mathrm{mg}$. Based on the ANOVA test results obtained there is a significantly different levels of uric acid with $p=0.038(<0.05)$ where the results of decreased of uric acid levels with the ethanol extracts of green gedi have a significant difference $(p<0.05)$ with ANOVA statistical tests with level of confidence $95 \%$.
\end{abstract}

Keywords : Anova, antyhiperuricemiaa, green gedy leaves.

\begin{abstract}
ABSTRAK
Di Kawasan Asia Tenggara menunjukan prevelensi untuk kejadian hiperurisemia, Indonesia menduduki peringkat kedua dengan angka 18\%. Penyakit akibat hiperurisemia (kelebihan asam urat) dikenal sebagai gout atau pirai. Penggunaan obat penurun asam urat seperti Allopurinol yang berlebihan atau terlalu sering dapat menimbulkan efek samping. Flavonoid diketahui dapat menghambat xantin oksidase, sehingga flavonoid berpotensi untuk dijadikan sebagai agen antihiperurisemia. Daun gedi hijau yang telah diekstraksi dengan etanol 96\% memiliki total kandungan flavonoid sebesar 41,56\%. Penelitian ini bertujuan untuk mengetahui potensi aktivitas penurunan kadar asam urat dari daun gedi hijau. Jenis penelitian ini merupakan penelitian eksperimental yang dilakukan didalam laboratorium dengan hewan uji tikus dengan 5 macam perlakuan setiap perlakuan dengan 3 kali pengulanan. Pengkondisian hiperurisemia dilakukan dengan menginduksi kalium oksonat secara intreperitoneal. Kelompok I sebagai kontrol negatif diberi CMC 1\%, kelompok II sebagai kontrol positif diberi Allopurinol, kelompok III- V diberi perlakuan ekstrak etanol daun gedi hijau dengan dosis yang berbeda-beda yaitu 3,6mg, 7,2mg, dan 14,4mg. Berdasarkan hasil uji ANOVA didapatkan kadar asam urat berbeda secara bermakna dengan $p=0,038(<0,05)$ dimana hasil penurunan kadar asam urat ekstrak etatnol daun gedi hijau terdapat perbedaan yang signifikan $(\mathrm{p}<0,05)$ dengan uji statistik ANOVA dengan tingkat kepercayaan $95 \%$.
\end{abstract}

Kata kunci : Daun gedi hijau, antihiperurisemia, Anova 


\section{PENDAHULUAN}

Asam urat merupakan hasil produksi tubuh, sehingga keberadaannya normal dalam darah dan urin. Akan tetapi sisa dari metabolisme protein makanan yang mengandung purin juga bisa menghasilkan asam urat. Kadar asam urat dalam darah bisa meningkat bila mengkomsumsi makanan yang mengandung purin tinggi (Misnadiarly, 2007).

Secara klinis obat hiperurisemia golongan urikostatik yang biasa digunakan saat ini adalah Allopurinol. Mekanisme kerja Allopurinol adalah dengan menghambat pembentukan asam urat yaitu dengan menghambat kerja enzim xantin oksidase. Efek samping dari allopurinol adalah gangguan gastrointestinal (mual, muntah dan diare), leukopenia, anemia aplastik, kerusakan hepar, nefritis interstisial dan hipersensitivitas (Price, 2005; Katzung et al., 2012).

Dalam beberapa penelitian flavonoid diketahui memiliki aktivitas biologis dan farmakologi, seperti antioksidan, antibakteri, antivirus dan efek antimutagenik. Flavonoid juga dapat menghambat beberapa enzim, seperti xantin oksidase, siklooksigenase, lipoksigenase dan fosfoinositida 3kinase. Xantin oksidase bersifat oksidatif dalam kerusakan jaringan hidup serta dapat menyebabkan hiperurisemia. Flavonoid mengkatalisis oksidasi hipoksantin dan xantin untuk asam urat (Lin et al., 2002).

$$
\text { Daun Gedi yang telah }
$$
diekstraksi dengan etanol $96 \%$ memiliki total kandungan flavonoid sebesar 41,56\% (Pine et al., 2015). Senyawa flavonoid mempunyai berbagai fungsi penting untuk kesehatan salah satunya sebagai antioksidan (Hodgson et al., 2006).

\section{METODOLOGI PENELITIAN}

\section{Waktu dan Tempat Penelitian}

Penelitian ini dilakukan di Laboratorium Lanjut Farmasi Program Studi Farmasi, Fakultas Matematika dan Ilmu Pengetahuan Alam, Universitas Sam Ratulangi Manado yang dimulai pada Mei 2019Agustus 2019.

\section{Alat dan Bahan}

\section{Alat}

Disposable syringe $1 \mathrm{~mL}$, alat ukur asam urat (Autocheck), oven, sonde oral, batang pengaduk, timbangan analitik (AE Adam $\left.{ }^{\circledR}\right)$, alat-alat gelas (pyrex), kertas saring, sarung tangan lateks, masker (SENSI Mask), botol sampel, blender (Philips), kandang pemeliharaan hewan dan ayakan biasa.

\section{Bahan}

Tikus putih jantan galur wistar (Rattus norvegicus) 15 ekor, daun Gedi (Abelmoschus manihot (L.) Medik), CMC (Carboxymethylce llulose), aquades, etanol 96\%, pakan tikus putih jantan galur wistar (Rattus norvegicus), Allopurinol $100 \mathrm{mg}$, kalium oksonat, aquades steril dan strip asam urat.

\section{Prosedur Penelitian}

\section{Penyiapan Hewan Uji}

Penelitian ini menggunakan tikus putih jantan galur wistar (Rattus 
norvegicus) sebagai hewan uji yang terbagi atas 5 kelompok uji dimana masing-masing kelompok terdiri atas 3 ekor tikus putih jantan galur wistar (Rattus norvegicus) yang dipelihara dalam kandang yang berisi dedak padi dan diberi pakan tikus.

\section{Pengambilan dan Penyiapan Sampel}

Tahap awal dilakukan dengan pengumpulan bahan baku daun Gedi (Abelmoschus manihot (L.) Medik) yang diambil dari daerah Minahasa Tenggara, Desa Molompar Utara. Daun Gedi dicuci bersih dengan air mengalir, ditiriskan dan ditimbang berat basahnya. Daun gedi yang telah dibersihkan diangin-anginkan didalam ruangan. Daun Gedi yang telah kering diblender sampai menjadi halus dan diayak menggunakan ayakan.

\section{Identifikasi Tanaman}

Identifikasi tanaman dilakukan dibagian Taksonomi Tumbuhan, Program Studi Biologi, Fakultas Matematika dan Ilmu Pengetahuan Alam, Universitas Sam Ratulangi, Manado.

\section{Pembuatan Ekstrak Daun Gedi} (Abelmoschus manihot (L.) Medik)

Daun Gedi yang telah menjadi serbuk simplisia ditimbang dan dimasukan kedalam wadah toples kemudian diekstraksi menggunakan metode maserasi dengan cara serbuk simplisia direndam dalam pelarut etanol $96 \%$. Perbandingan antara bahan dan pelarut adalah 1:5 (w/v) dan dibiarkan selama 3 hari sambil sesekali diaduk kemudian disaring menggunakan kertas saring kemudian diremaserasi dengan pelarut dan perbandingan yang sama dibiarkan selama 2 hari sambil sesekali diaduk lalu disaring menggunakan kertas saring. Filtrat yang diperoleh yaitu filtrat 1 dan filtrat 2 dicampur dan dipekatkan menggunakan oven pada suhu $40^{\circ} \mathrm{C}$ sampai diperoleh ekstrak kental.

\section{Pembuatan Larutan CMC 1\%}

Larutan stok CMC 1\% dibuat dengan cara 1 gram serbuk CMC didalam $\quad 100 \mathrm{~mL}$ aquades, dihomogenkan dengan cara pemanasan mengguakan hot plate, kemudian didinginkan. Perbandingan antara aquades dengan CMC adalah 100:1 artinya didalam $100 \mathrm{~mL}$ aquades terdapat 1 gram CMC.

\section{Pembuatan Larutan Uji}

Pembuatan larutan uji ekstrak etanol daun Gedi (Abelmoschus manihot (L.) Medik) sesuai dengan masing-masing dosis (200mg, 400mg dan $800 \mathrm{mg}$ ), pemberian dosis terlebih dahulu dikonversikan dengan menggunakan faktor konversi untuk manusia ke tikus 200gram ialah 0,018. Masing-masing ekstrak etanol daun Gedi (Abelmoschus manihot (L.)Medik) ditimbang sesuai dosis kemudian ditambahkan $1 \mathrm{~mL}$ larutan CMC $1 \%$ dan diaduk sampai homogen. Setelah homogen, masingmasing dosis ekstrak dimasukan dalam botol sampel dan diberi label DSI untuk ekstrak etanol daun Gedi dengan dosis 3,6mg; DSII untuk ekstrak etanol daun Gedi dengan dosis 7,2mg; dan DSIII untuk ekstrak etanol daun Gedi dengan dosis 14,4mg. 


\section{Pembuatan Larutan Allopurinol}

Dosis Allopurinol pada manusia dewasa adalah $100 \mathrm{mg} /$ hari.Takaran konversi dosis manusia ke dosis tikus ialah 0.018 . Kemudian dibuat dalam larutan stok 10 $\mathrm{mL}$.

\section{Pembuatan Larutan Kalium Oksonat}

Dosis efektif kalium oksonat sebagai inhibitor urikase yaitu $250 \mathrm{mg} / \mathrm{Kg} \mathrm{BB}$ dengan pemberian intraperitoneal (Suhedi et al., 2011). Kemudian dibuat dalam larutan stok $20 \mathrm{~mL}$.

\section{Pemberian Perlakuan}

Pemberian perlakuan untuk penelitian ini masing-masing konsentrasi menggunakan 3 hewan uji dengan total 15 ekor tikus jantan galur wistar, sebelum diberi perlakuan hewan uji dipuasakan terlebih dahulu.Allopurinol, CMC $1 \%$ dan Ekstrak etanol daun Gedi (Abelmoschus manihot (L.) Medik) diberikan sesuai dengan dosis perlakuan secara oral dengan pensuspensi CMC $1 \%$ sebanyak $1 \mathrm{~mL}$ menggunakan alat penyekok oral (sonde) dengan dispo.

\section{Pengambilan Darah}

Pengambilan darah dilakukan sebanyak 5 kali. Sampel darah diambil melalui vena ekor tikus putih jantan galur wistar (Rattus norvegicus) menggunakan alat pengukur kadar asam urat Autocheck.

\section{Analisis Data}

Data kuantitatif yang diperoleh dianalisis menggunakan Analysis of Variance (ANOVA) untuk mengetahui pengaruh ekstrak etanol daun Gedi (Abelmoschus manihot (L.) Medik) terhadap kadar asam urat pada tikus dan menggunakan Least Significant Difference (LSD) untuk menguji signifikasi dari perbedaan rata-rata antar kelompok perlakuan.

\section{HASIL DAN PEMBAHASAN}

Pemilihan tikus putih jantan galur wistar yang berumur 2-3 bulan dengan berat badan \pm 150 gram sebagai hewan uji dikrenakan menurut Hakim (2002) tikus putih jantan galur wistar memiliki kemiripan dengan manusia dalam hal fisiologi, anatomi, patologi atau metabolisme. Jenis kelamin jantan digunakan karena memiliki kecepatan metabolisme dan tidak terpengaruh oleh perubahan hormonal dibandingkan dengan tikus betina, karena tikus betina mengalami siklus uterus masa kehamilan dan menyusui. Selain itu tikus jantan tidak memiliki hormon estrogen, walaupun ada jumlahnya sangat sedikit. Hormon estrogen dapat meningkatkan ekskresi asam urat.

Pengkondisian Hiperurisemia pada tikus dibuat dengan menginduksi masing-masing hewan uji menggunakan kalium oksonat dengan dosis $50 \mathrm{mg}$ secara intraperitoneal per satu kali pemberian setelah sampel darah diperoleh. Kalium Oksonat diinjeksikan kedalam rongga perut tanpa mengenai organ lain, di dalam rongga perut kalium oksonat akan langsung diabsorbsi ini dikarenakan rongga peritoneum mempunyai permukaan absorbsi yang sangat luas sehingga kalium oksonat dapat masuk ke sirkulasi sistemik secara cepat dan 
kenaikan kadar asam urat akan cepat dicapai.

Setelah pemberian kalium oksonat kadar asam urat akan mencapai puncak tertinggi pada waktu

2 jam dan kadarnya akan menurun hingga mencapai normal setelah 8 jam penginduksian (Huang et al., 2008). Maka dari itu penelitian dilakukan selama 6 jam karena setelah jam ke-6 kalium oksonat sudah memasuki fase penurunan aktivitas.

Sebelum perlakuan kalium oksonat kadar asam urat tikus diuku terlebih dahulu yaitu kadar asam urat tikus puasa (t0) tujuan dilakukan pengukuran kadar asam urat adalah untuk mengetahui kadar asam urat adalah untuk mengetahui kadar asam urat pada tikus sebelum perlakuan kalium oksonat atau sebagai base line dari pengujian. Pada Tabel 1 rata-rata pengukuran kadar asam urat tikus adalah antara 3,6 $\mathrm{mg} / \mathrm{dL}$ sampai dengan $7,7 \mathrm{mg} / \mathrm{dL}$.

Tabel 1. Hasil pengukuran kadar asam urat

\begin{tabular}{|c|c|c|c|c|c|c|}
\hline \multirow[t]{2}{*}{ Perlakuan } & \multicolumn{6}{|c|}{ Kadar Asam Urat ( mg/dL ) Pada Waktu } \\
\hline & t0 & $\mathrm{t} 1$ & & $\mathrm{t} 2$ & $\mathrm{t} 4$ & t6 \\
\hline Kontrol Negatif & 7,7 & 11,3 & CMC $1 \%$ & 6,7 & 5,3 & 2,9 \\
\hline Kontrol Positif & 4,8 & 3,6 & Allopurinol $100 \mathrm{mg}$ & 3,1 & 2,9 & 3,3 \\
\hline Dosis I & 5,0 & 5,1 & EEDGH 200mg & 5,2 & 7,2 & 3,9 \\
\hline Dosis II & 3,6 & 5,0 & EEDGH 400mg & 5,7 & 6,2 & 5,4 \\
\hline Dosis III & 3,7 & 5,9 & EEDGH 800mg & 2,9 & 3.0 & 2,9 \\
\hline
\end{tabular}

Pengkondisian hiperurisemia yaitu dengan menginduksikan kalium oksonat secara intraperitoneal, 1 jam setelah diinduksi kalium oksonat kadar asam urat tikus diukur (t1). Pada tabel 1 rata-rata pengukuran kadar asam urat (t1) adalah antara 5,0 mg/dL sampai dengan 11,3 $\mathrm{mg} / \mathrm{dL}$ dapat dilihat perbandingan antara t0 dan t1 yaitu terjadi peningkatan kadar asam urat sebelum dan setelah diinduksi kalium oksonat dan peningkatan kadar asam urat normal dalam darah sehingga hal ini menunjukan adanya keberhasilan pengkondisian hiperurisemia sehingga hal ini menunjukan adanya keberhasilan pengkondisian hiperurisemia, walaupun tidak semua kelompok perlakuan mengalami peningkatan kadar asam urat. Kadar asam urat tikus pada batas normal 1,2-5,0 mg/dL.

Ket :

t0 Pemeriksaan Kadar Asam Urat

: $\quad$ sebelum diinduksi kalium oksonat Pemeriksaan Kadar Asam Urat setelah 1 jam penginduksian

t1 : kalium oksonat

t2 : Pemeriksaan Kadar Asam Urat setelah 2 jam penginduksian kalium oksonat

t4 : Pemeriksaan Kadar Asam Urat 
setelah 4 jam penginduksian kalium oksonat

t6 : Pemeriksaan Kadar Asam Urat setelah 6 jam penginduksian kalium oksonat.

EEDGH: Ekstrak Etanol Daun Gedi Hijau

Kadar asam urat diukukur sebanyak 5 kali selama 6 jam pengamatan dimana kadar asam urat diukur dengan interval waktu yang berbeda-beda. Kadar asam urat tikus puasa (t0) diambil setelah tikus dipuasakan selama 8 jam dan hanya diberi minum, hal ini bertujan agar pangan tikus tidak mempengaruhi kenaikan maupun penurunan kadar asam urat. Pengukuran kadar asam urat selanjutnya diukur setelah 1 jam penginduksian kalium oksonat secara intraperitoneal.

Hal ini dilakukan untuk melihat kenaikan kadar asam urat setelah diinduksi.

Diberikan CMC 1\% untuk kontrol negatif, Allopurinol untuk kontrol positif. Menurut Hakim (2002), kontrol negatif bertujuan untuk mengontrol hasil yang diperoleh dari kelompok perlakuan dan bertujuan untuk memberikan validitas yang tinggi dalam suatu penelitian, sedangkan untuk kontrol positif bertujuan untuk mengkonfirmasi validitas metode dan prosedur penelitian serta sebagai suatu rujukan bagi senyawa, obat baru ataupun bahan alam yang sedang diteliti sehingga ditemukan potensi relatif terhadap obat tersebut.

Ekstrak etanol daun gedi hijau dengan dosis yang berbeda yaitu 0,0036 gram (200mg) untuk dosis I, 0,0072 gram (400mg) untuk dosis II, dan 0,0144 gram (800mg) untuk dosis III diberikan secara per oral. Hal tersebut dilakukan karena pada waktu (t1) dapat dilihat pada Tabel 1 dimana kadar asam urat hewan uji telah meningkat melewati batas normal. 1 jam setelahnya dilakukan pemeriksaan kadar asam urat kembali karena menurut Huang et al (2008) kadar asam urat akan mencapai puncak tertinggi pada waktu 2 jam setelah induksi secara intraperitoneal. Pemeriksaan kadar asam urat selanjutnya dilakukan pada jam ke- 4 dan ke- 6 setelah dinduksi kalium oksonat secara intraperitoneal hal ini dilakukan yaitu untuk menyesuaikan pemeriksaan kadar asam urat di jam ke- 2 .

Hasil pengukuran kadar asam urat tikus dapat dilihat pada Gambar 3 Dari grafik yang diperoleh dapat dilihat terjadi kenaikan kadar asam urat mencapai puncak sampai $15,5 \mathrm{mg} / \mathrm{dL}$ setelah 1 jam diinduksi kalium oksonat (t0) dan penurunan kadar asam urat sedikit demi sedikit sampai jam ke- 6 (t6) setelah pemberian ekstrak daun gedi hijau dan Allopurinol.

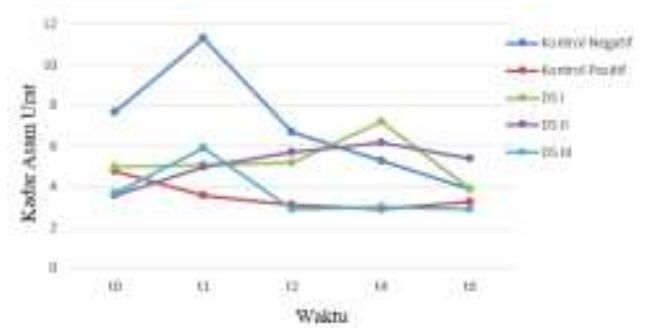

Gambar 4. Grafik rata-rata pengukuran kadar asam urat 


\begin{abstract}
Allopurinol sering digunakan sebagi terapi farmakologi untuk menurunkan asam urat. Di dalam hati, Allopurinol dimetabolisme sehingga mengahasilkan metabolit aktifnya yaitu oksipurinol (aloxantin), oksipurinol ini akan menghambat xantin oksidasi untuk mengubah xantin menjadi asam urat. Terjadi penurunan secara nyata setelah pemberian Allopurinol (kontrol positif) dapat dilihat pada Tabel 1 .
\end{abstract}

Aktivitas yang sama ditunjukan oleh ketiga kelompok ekstrak etanol daun gedi hijau. Terjadi penurunan kadar asam urat pada ketiga dosis ekstrak etanol daun gedi hijau sampai pada jam ke-6 (t6) sampai kadar normal. Hal ini dikarenakan didalam ekstrak etanol daun gedi mengandung flavonoid yang berdasarkan penelitian sebelumnya Dewantara (2017) menjelaskan bahwa ekstrak etanol daun gedi hijau yang di uji dengan pereaksi Wilstater menunjukan adanya flavonoid, di mana pada saat direaksikan terbentuk larutan berwarn kuning. Menurut Van Hoorn et al (2002), flavonoid dapat menghambat xantin oksidasi. Hubungan antara struktur flavoinoid dengan aktivitasnya sebagi inhibitor xantin oksidasi dikarenakan adanya gugus hidroksil (gugus -OH) pada C-5 dan C-7 serta ikatan rangkap antara C-2 dan C-3. Dengan adanya ikatan rangkap pada atom C-2 dengan C-3 sehingga mengakibatkan posisi ring $\mathrm{B}$ co-planar terhadap ring A hingga memudahkan dalam berinteraksi dengan xantin oksidasi. Hal ini menunjukan bahwa kelompok perlakuan ketiga dosis ekstrak etanol daun gedi hijau dan kontrol positif dapat menurunkan aktivitas hiperurisemia oleh penginduksian kalium oksonat. Adapun kelemahan dari penelitian ini seringkali mendapat kesulitan pada saat menaikan kadar asam urat (pengkondisian hiperurisemia) dan pada saat pemeriksaan asam urat, harus dilakukan dengan teliti terutama pada saat perhitungan kalium oksonat karena dapat mengganggu atau dapat mempengaruhi hasil. Perhitungan dosis kalium oksonat dan pemilihan alat ukur asam urat serta pengukuran harus diperhatikan sehingga tidak mempengaruhi hasil (data peneitian).

Untuk mendapatkan data yang lebih spesifik mengenai pengaruh ekstrak etanol daun gedi hijau terhadap penurunan kadar asam urat tikus di setiap kelompok perlakuan maka dilakukan uji statistika berupa ANOVA dan LSD(Least Significant Difference).

Tabel 2. Hasil uji Test Homogenity of Variance

Test of Homogeneity of Variances
Penurunan Kadar Asam Urat
\begin{tabular}{|c|c|c|c|}
\hline $\begin{array}{c}\text { Levene } \\
\text { Statistic }\end{array}$ & df1 & df2 & Sig. \\
\hline 1.954 & 4 & 20 & .141 \\
\hline
\end{tabular}

Uji homogenitas adalah suatu uji yang dilakukan untuk mengetahui bahwa dua atau lebih kelompok data sampel berasal dari populasi yang memiliki varian sama (homogen). Dari hasil yang telah dianalisis menunjukan $\mathrm{p}=0,141$ di mana nilai $\mathrm{p}>0,05$, maka dapat disimpulkan bahwa varian data yang ada homogen. 
Uji statistic one-way ANOVA (Analysis of Variance) dilakukan untuk mengetahui adanya aktivitas penurunan kadar asam urat ekstrak etanol daun gedi hijau terhadap tikus putih jantan galur wistar. Untuk mengetahui data hasil one-way ANOVA dapat dilihat Tabel 3 berikut ini :

Tabel 3. Hasil Uji ANOVA

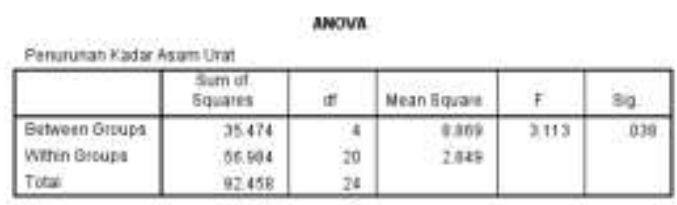

Hasil uji ANOVA menunjukan terdapat perbedaan yang bermakna dengan nilai $\mathrm{p}=0,038(\mathrm{p}<0,05)$ di mana hasil yang ditunjukan hipotesis menolak H0 dan menerima H1, maka didapatkan hasil bahwa aktivitas penurunan kadar asam urat tikus setelah pemberian ekstrak etanol daun gedi hijau terdapat perbedaan yang signifikan.

Uji LSD (Least Significant Difference) dilakukan untuk menguji signifikansi dari perbedaan rata-rata antar kelompok perlakuan. Dari Tabel 4 dapat dilihat signifikansi dari perbedaan rata-rata antara kelompok perlakuan, terdapat perbedaan yang bermakna antara kontrol negatif yang diberi CMC $1 \%$ dan kontrol positif yang diberi Allopurinol dengan $\mathrm{p}=0,007(<0,05)$ di mana hasil yang ditunjukan hipotesis menolak H0 dan menerima H1, maka didapatkan hasil bahwa terdapat perbedaan yang bermakna antara kontrol positif dan kontrol negatif. Dari ketiga dosis, dosis III yang paling mendekati kontrol positif dengan $\mathrm{p}=$ $0,897(>0,05)$ di mana hasil yang diperoleh hipotesis menerima $\mathrm{HO}$ dan menolak H1, maka tidak terdapat perbedaan yang bermakna antara kontrol positif dan dosis III sehingga dosis III berpotensi menurunkan kadar asam urat.

Tabel 4. Hasil Uji LSD

\begin{tabular}{|c|c|c|}
\hline Kelompok & $\mathrm{p}$ & Keterangan \\
\hline \multirow[t]{2}{*}{ I-II } & 0,007 & Berbeda \\
\hline & & Signifikan \\
\hline \multirow[t]{2}{*}{ I-III } & 0,175 & Tidak \\
\hline & & Berbeda \\
\hline \multirow[t]{2}{*}{ I-IV } & 0,150 & Tidak \\
\hline & & Berbeda \\
\hline \multirow[t]{2}{*}{ I-V } & 0,009 & Berbeda \\
\hline & & Signifikan \\
\hline \multirow[t]{2}{*}{ II-I } & 0,007 & Berbeda \\
\hline & & Signifikan \\
\hline \multirow[t]{2}{*}{ II-III } & 0,119 & Tidak \\
\hline & & Berbeda \\
\hline \multirow[t]{2}{*}{ II-IV } & 0,140 & Tidak \\
\hline & & Berbeda \\
\hline \multirow[t]{2}{*}{ II-V } & 0,897 & Tidak \\
\hline & & Berbeda \\
\hline \multirow[t]{2}{*}{ III-I } & 0,175 & Tidak \\
\hline & & Berbeda \\
\hline \multirow[t]{2}{*}{ III-II } & 0,119 & Tidak \\
\hline & & Berbeda \\
\hline \multirow[t]{2}{*}{ III-IV } & 0,926 & Tidak \\
\hline & & Berbeda \\
\hline \multirow[t]{2}{*}{ III-V } & 0,150 & Tidak \\
\hline & & Berbeda \\
\hline \multirow[t]{2}{*}{ IV-I } & 0,150 & Tidak \\
\hline & & Berbeda \\
\hline \multirow[t]{2}{*}{ IV-II } & 0,140 & Tidak \\
\hline & & Berbeda \\
\hline \multirow[t]{2}{*}{ IV-III } & 0,926 & Tidak \\
\hline & & Berbeda \\
\hline \multirow[t]{2}{*}{ IV-V } & 0,175 & Tidak \\
\hline & & Berbeda \\
\hline \multirow[t]{2}{*}{ V-I } & 0,009 & Berbeda \\
\hline & & Signifikan \\
\hline \multirow[t]{2}{*}{ V-II } & 0,897 & Tidak \\
\hline & & Berbeda \\
\hline
\end{tabular}




\begin{tabular}{|c|c|c|}
\hline V-III & 0,150 & $\begin{array}{c}\text { Tidak } \\
\text { Berbeda } \\
\text { Tidak } \\
\text { Verbeda }\end{array}$ \\
\hline
\end{tabular}

\section{Ket :}

I : Kontrol Negatif

II : Kontrol Positif

III : Dosis I

IV :Dosis II

V : Dosis III

\section{KESIMPULAN}

Pemberian ekstrak etanol daun gedi hijau (Abelmoschus manihot (L.) Medik) memiliki pengaruh terhadap penurunan kadar asam urat tikus putih jantan galur wistar (Rattus norveggicus), dengan Hasil Uji ANOVA pada taraf uji 0,05 menunjukan hasil bahwa terdapat perbedaan yang bermakna antar kelompok perlakuan dan dengan hasil uji LSD (Least Significant Difference) menunjukan terdapat perbedaan yang bermakna antara dosis III (800mg) dan kontrol negatif dan tidak terdapat perbedaan yang bermakna antara dosis III (800mg) dan kontrol positif sehingga dapat disimpulkan dosis III (800mg) memiliki aktivitas atau berpetensi sebagai antihiperurisemia.

\section{SARAN}

Perlu adanya penelitian lebih lanjut untuk mengetahui senyawa lain selain flavonoid yang terkandung dalam daun gedi hijau yang dapat berperan dalam menurunkan kadar asam urat dan perlu dilakukan uji toksisitas.

\section{DAFTAR PUSTAKA}

Dewantara, I. Ketut. G. D. 20017. Uji Potensi Ekstrak Etanol Daun
Gedi Abelmoschus manihot L.)

Terhadap

Aktivitas

Antioksidan dan Penurunan

Kadar Glukosa Darah Tikus

Putih Galur Wistar Yang

Diinduksi Aloksan. Cakra

Kimia (Indonesia E- Journal of

Applied Chemistry) 5(2) : 94-

101.

Hakim, L. 2002. Uji Farmakologi dan Toksikologi Obat Alam Pada Hewan Coba. Prosiding Seminar Herbal Medicine. Universitas Muhamadiyah Purwokerto. Hlm 1-21

Hodgson, J. M., dan Kevin, D. 2006. Review Dietary Flavonoids : Effects on Endothelial Function and Blood Pressure. Journal Science Food Agriculture. 86: 2492-2498.

Huang, Shang, Zhang, Li, dan Jiao. 2008. Hypouricemic Effects of Phenylpropanoid Glycosides Acteoside of Scrophularia ningpoensis on Seru Uric Acid Levels in Pottasium OxonatePretreated Mice. The American Journal of Chinese Medicine. 36(1): 149-157.

Katzung, B.G.,Masters, S.B., dan Trevor, A.J. 2012. Basic and Clinical Pharmacology. Ed ke2. Mc Graw Hill, New York.

Lin, Chen, Liang dan Lin. 2002. Molecular Modeling of Flavonoids that Inhibits Xanthine Oxidase. Biochemical and Biophysical Communication. 294: 167-172.

Misnadiarly. 2007. Rematik : Asam Urat, Hiperuriseia, Arthritis Gout. Pustaka Obor, Jakarta 
Pine, A.T.D., Alam, G., dan Attamin, F. 2015. Standarisasi Mutu Ekstrak Daun Gedi (Abelmoschus manihot L. Medik) dan Uji Efek Antioksidan dengan Metode DPPH. JF FIK UINAM. 3 (3):111128

Price, A.S., dan Wilson, M.L. 2005. Patofisiologi Konsep Klinik Proses-Poses Penyakit. EGC, Jakarta.

Suhedi, Nurcahyati, Muhtadi dan Sutrisna. 2011. Aktivitas Antihiperurisemia Ekstrak Air Jinten Hitam (Coleus ambonicul Lour) pada Mencit Jantan Galur Balb-C dan Standarisasinya. Majalah Farmasi Indonesia. 22(2): 77-84.

Van Hoorn, D. E. C., Nijveldt, R. J., Van Leuwen, P. A. M., Hofman, Z., M'Rabet, L., De bont, D. B. A., dan Van Norren, K. 2002. Accurate Prediction Of Xanthine Oxidase Inhibition Based on the Structure of Flavonoids. European Journal of Phamacology. 451: 111-118. 